\title{
UNLOCKING THE POTENTIAL OF TRANSLATION FOR FLT
}

\section{INTRODUCTION}

"The language of Europe is translation." With these words Umberto Eco summarized his vision of the linguistic landscape of Europe in his lecture delivered at the Assises de la Traduction littéraire in Arles in 1993 and thereby underlined the importance of translation skills as a vehicle of communication between European Union citizens and across language and cultural barriers. In light of this vision, any type of foreign language education pursuing a communicative purpose should entail a certain amount of translation skills and be designed by taking into account the findings of translation studies. And yet, when studying the relationship between the domains of foreign language teaching ${ }^{1}$ (FLT) and translation studies (TS) what comes to the fore is a kind of love-hate attitude that has marked the interlinked development of these two disciplines.

The appearance of the Common European Framework of Languages (CEFR), developed by the Council of Europe in 2001, marked a turning point in FLT. The CEFR was introduced as a common basis for the explicit description of objectives, content and methods for language education and was aimed at enhancing the transparency of language courses, syllabuses and qualifications, while promoting international co-operation in the field of modern languages (CEFR 2001: 1). The CEFR proposed a model of communicative competences, including communicative language competences as those which enable a person to act by drawing on specific linguistic means (CEFR 2001: 9), and although it did not explicitly refer to any FLT methodology it shifted the emphasis on communicative proficiency and intercultural competences as the ultimate objectives to pursue in FLT thereby raising the awareness of the importance of multilingual and multicultural competency (Pižorn and Brumen 2008). Communicating across language and cultural barriers, however, is possible only by using (some degree) of translation, and this speaks in favour of drawing on the potential of TS to enhance intercultural communicative competence. However, as regards its relation to translation, the CEFR seems to have taken over (at least partly) the heritage of some of the FLT approaches that marked the second half of the $20^{\text {th }}$ century, as it somehow fails to acknowledge the fact that translation underlies and permeates language use in intercultural communication and that it represents one of the most obvious manifestations of plurilingualism and pluriculturality. In the history of

* Author's address: Pedagoška fakulteta, Univerza na Primorskem, Cankarjeva 5, 6000 Koper, Slovenia. E-mail: alenka.kocbek@pef.upr.si.

1 For the purpose of this paper no distinction will be made between second and foreign language teaching, and the term foreign language teaching (FLT) will be used to refer to both. 
FLT the role granted to translation has been extremely unstable. Once considered a fundamental teaching method and basic skill, one placed at the heart of any language learning process, translation was almost outlawed in more recent communicative and task-based approaches to language learning (Cook 2010: 3), then rehabilitated in recent decades (cf. Leonardi 2010; Cook 2010; Widdowson 2003; Malmkjær 1998; Bratož and Kocbek 2013; Kocbek 2013), and finally elevated to the position of the fifth language skill (cf. Leonardi 2010; Naimushin 2002). What is striking about both the history of FLT and TS is the fact that the two disciplines seem to have developed separately for quite a long period, without managing to establish points of contact; consequently, they have missed the opportunity to create important synergies (cf. Tsagari and Floros 2013: vii-xi). The CEFR, currently generally accepted as the most authoritative source of guidelines and principles for teaching, learning and assessing modern languages in Europe, still explicitly refers to translation and interpreting, i.e. written or oral mediation, as varieties of language use and language activities through which communicative language competence is activated (CEFR 2001: 14, 55). Translation and interpreting in this view are deemed as (professional and/or non-professional) activities performed by language users to enable communication between third parties who, for whatever reasons, are unable to communicate directly (ibid.) This somewhat narrow view of translation neglects the multiple aspects of translation entailed in communicative acts involving participants from different cultures and with different linguistic backgrounds who, when communicating by using a foreign language (FL), resort to translation, an act which is often performed tacitly and almost automatically. Nevertheless, the CEFR implicitly acknowledges the status of TS when it deals with different aspects of communication, i.e. its verbal, paraverbal, non-verbal and sociocultural dimensions. These aspects have also been given prominence in various TS theories, especially the functionalist and culturally-oriented approaches and particularly in the cultureme theory. Drawing on the works of authors who have advocated the use of translation in FLT (Kocbek 2013; Leonardi 2010; Cook 2010; Widdowson 2003; Malmkjær 1998; Naimushin 2002), this paper aims at rendering justice to the explicit and implicit role of translation in FLT and exploring the potential synergies that could be achieved by combining the findings of FLT and TS. It thus suggests that translation be viewed as an additional language skill that is aimed at supplementing the traditional four skills, while using translation to create a comprehensive approach to language learning (Leonardi 2010: 25). In this respect the approach also entails transferring selected insights from TS into FLT (e.g. the functionalist perspective with the skopos theory, the cultureme theory, the theory of memes) to raise the learners' awareness about aspects of language use that are shaped by extra-linguistic factors. In this view translation is not regarded as the only legitimate teaching method but rather as a pedagogical tool or scaffolding strategy aimed at increasing the effectiveness of various FLT approaches.

\section{FOREIGN LANGUAGE TEACHING AND TRANSLATION STUDIES - ALLIES OR FOES}

In the past century FLT underwent significant developments and status shifts accompanying different teaching methods and strategies. An important turn in this respect 
was the abandoning of the teaching practices of the Grammar-Translation Method, which had marked FLT in the $19^{\text {th }}$ and the first half of the $20^{\text {th }}$ century, and focused principally on formal accuracy in writing, thus failing to acknowledge the communicative function of language. As the name itself indicates, this method relied heavily on translation, which was applied primarily in the light of the so-called equivalence-based approaches that were viewed in a very restricted perspective, i.e. mostly as word-forword semantic equivalence. In the second half of the $20^{\text {th }}$ century, the Grammar Translation Method (GTM) was seen as obsolete and ineffective and it was substituted by a number of other approaches, the most prominent being the communicative approach, which is applied in the form of communicative language teaching (CLT). In line with several other teaching methods popular in the last decades (e.g. the Direct Method), CLT uncritically rejected the use of the learners' first language (L1) in the classroom and ostracised translation in second language instruction while promoting the doctrine of monolingualism in the classroom. Proponents of CLT argued that the use of the L1 was counterproductive in the process of acquiring a new language, as it hindered learners in their striving to express themselves in the FL and caused interference and possible negative transfer. This animosity against translation actually resulted in its being banned from the language curricula in many countries. In France, for example, such a ban was actually imposed by legislation in 1950, namely, with the official introduction of the Direct Method through ministerial guidelines (Carreres 2006: 2). Criticism opposing the use of translation in the language classroom failed to recognise that, in the GTM, translation had actually been misconceived and overused and that therefore, rather than being considered the source of the ineffectiveness and inadequacy of this method, it should be seen as its victim (ibid.: 4). In the GTM learners were very often made to translate isolated sentences without being provided with any wider meaningful context. In this way the GTM abstracted language from its communicative function and neglected the fact that in real life translation is used almost exclusively to enable communication. But even when translation was officially rejected as a FLT method, it did not disappear from language classes - it continued to be used unofficially by learners in different ways, least but not last, as pointed out by Widdowson (2003), to tacitly translate in their minds. It was also maintained as the norm at university-level language teaching, especially in LSP (Malmkjær 1998).

Spurred by the wave of monolingualism and the hostility towards translation in FLT, the myth of the native-speaker as the ideal FL teacher was created. As pointed out by House, the opposition to L1 use and translation, which stemmed from ideas of natural language use and from native speaker emulation, was particularly fervent in the English speaking world and hence also affected the practice of the teaching of English as a FL (House 2012: 216). The reasons for this monolingual puritanism were not exclusively scientific, as emphasized by House (ibid.: 219), but were, among other things, driven by commercial and political (Anglo-American) interests of creating a worldwide market for teaching materials, methods, etc. It needs to be noted that the global English teaching industry is believed to be worth 13.8 billion euros (Graddol: 2004), which indeed provides a solid motive for publishing English-only textbooks and promoting 
monolingual teachers, as well as for hiding the positive roles of translation (cf. Pym, Malmkjær and Gutiérrez-Colón Plana 2012). The hostility towards translation was also extended (as a kind of collateral damage) to the use of contrastive analysis in FLT, which, like translation, is only possible by referring to the learners' L1.

That being said, it needs to be emphasized that in non-English speaking countries dissenting voices advocating the use of $\mathrm{L} 1$ and translation were heard relatively early on, proving that the non-Anglophone environments never completely abandoned the use of L1 and/or translation in FLT (cf. House 2012: 217). In this respect, Naimushin (2002) argues in favour of recognizing translation and interpreting skills as an important element of the communicative and linguistic competence, i.e. as the fifth skill. According to Newmark (1991) this skill exists alongside the traditional four language skills developed by FLT. Without embracing the concept of translation as an independent skill, Leonardi (2010: 20) sees it as an effective means of enhancing and further developing reading, writing, speaking and listening skills and proposes to include translation activities into language testing modalities. She also argues that the CEFR as a widely recognised pedagogical tool for determining proficiency levels has failed to include translation among the different testing modalities which are still based on the four traditional skills. By stressing that in order to make the best use of translation in FLT, the FL teacher needs to have a good command of the learners' L1, Naimushin challenges the myth of the superiority of the native speaker as a FL teacher. He points out that a teacher who is not proficient in his students' $\mathrm{L} 1$ and is therefore unable to resort to translation will be unable to make sure that his/her explanations are fully understood, and neither will he/she be able to provide any systematic comparison between the students' L1 and the FL. Translation (and interpreting) create opportunities for contrastive analysis between the mother tongue and the FL on various levels, including phonology, morphology, syntax and lexis, which can serve as a valuable tool in making learners understand systemic and functional equivalence between linguistic units and recognise similarities and differences at various levels of L1 and FL, thus minimising the possibilities of negative interference and transfer (Naimushin 2002: 48). In this respect Leonardi argues that interference is a phenomenon occurring in language acquisition in general, as it is impossible and almost unnatural not to refer to one's L1 when using a FL. Translation skills, however, enable learners to notice and control interference through contrastive analysis and thus reduce negative transfer, while at the same time increasing positive interference, e.g. facilitation (Leonardi 2010: 27-28).

The above mentioned stances show "that translation is no longer seen as a harmful tool in language learning" and that "its interference tends to be positively evaluated as a way to enrich rather than harm learners' competence and performance" (Leonardi 2010: 18). These stances are to be interpreted as a sign of the revival of translation in FLT and, at the same time, of the need to refer to TS for targeted strategies supporting FLT. Almost concurrently with the evolution of FLT, TS rose to the status of an independent discipline and underwent a period of burgeoning development. During this period, the equivalence-centred perspective was gradually abandoned in order to embrace broader views by taking into account the different factors involved in the process of translating, 
from the function of translation to its essential role in intercultural communication and its cognitive connotations. By endorsing the arguments of the above mentioned authors in favour of combining the potentials of FLT and TS, we will propose to use translation activities in FLT to supplement the four traditional language skills, while at the same time applying some targeted insights and strategies from TS which can contribute to improving the learners' communicative proficiency and intercultural competence in the light of the CEFR as a source of FLT guidelines and principles.

\section{TRANSLATION AS AN AID TO FLT}

As shown above, any use of a FL by a non-native speaker implies some degree of translating. We would like to argue that, on the one hand, FL learners will benefit from being involved in translation activities aimed at enhancing and strengthening reading, writing, listening and speaking skills, while, one the other hand, they will, by gaining insight into some of the aspects highlighted by TS (such as the importance of the purpose of the translation for effective communication, the multifaceted nature of intercultural communicative acts, the potential of translation as a vehicle of transferring highly culture-specific concepts and practices), also be able to use translation in support of effective communica$\operatorname{tion}^{2}$. Among the approaches which endorse this perspective we would like to highlight the functionalist perspective with the skopos theory (Reiss and Vermeer 1984), according to which translation can take a number of forms and pursue different strategies depending on its purpose (i.e. the skopos) and will thus be essential to enable effective cross-cultural communication. Furthermore, we suggest applying the cultureme model, as elaborated by Kocbek (2013) following Oksaar (1988) and use it as a scaffolding tool for tackling the multifaceted aspects of communicative acts and thus develop cross-cultural communicative competences in a holistic way. Another related theory which upholds the use of translation in FLT is the theory of memes, where translation is seen as the only possible vehicle for transferring culturally-bound concepts, ideas, cultural practices (i.e. memes) across cultural and linguistic boundaries (Chesterman 1997). We thus suggest viewing translation as a useful and necessary competence in its own right, and one which not only enables learners to use the FL efficiently, but also, as Cook (2010: 100) points out, empowers learners "to move back and forth between L1 and L2" by taking into account the cultures underlying these languages and thus implementing the principles of plurilingualism and pluriculturality promoted by the CEFR.

A further positive effect which can be achieved by using translation in FLT is the fact that giving learners the possibility to occasionally resort to L1 and translation may make them feel more confident and reduce the anxiety caused by a monolithic FL environment, i.e. contribute to lowering their affective filter, in accordance with Krashen (1982), and thus enhance language acquisition.

2 For the purpose of this paper only pedagogical translation, i.e. translation as a means of enhancing language skills and intercultural competences of FL learners (cf. Leonardi 2010) will be considered. We leave aside the role of translation used in the training of professional translators (i.e. translation pedagogy), since it lies beyond the scope of this study. 


\subsection{Translation supplementing the four traditional language skills}

One of the frequently voiced objections to including translation into FLT is that it is a merely mechanical activity; however, as shown by Leonardi, the translation process actually involves a series of activities based on and implying reading, writing, speaking and listening (2010: 23-24). For example, when translating, the source text (ST) needs to be read very carefully and analysed in detail before proceeding to produce a target text (TT). Actually, the degree of attention required when reading a ST for translation purposes is generally higher than in reading activities for didactic purposes. As in teaching reading skills, the ultimate goal is to prepare learners to read different kinds of texts (depending on their age, proficiency level, and the type of language education they are involved in), and the fact that learners tend to translate mentally into their L1 when reading FL texts can be used profitably by externalising their thoughts and mental translations through cooperative translation activities aimed at enhancing comprehension. By applying contrastive analysis to syntactical and lexical aspects of texts, learners can be made aware of specific aspects of FL texts that may hinder understanding (e.g. positioning the conjugated verb form at the very end of subordinate clauses in German, expressing understatement by using double negatives, i.e. litotes, in English texts).

Since by its very definition translation involves transposing a (written or spoken) text from a source language (SL) into a target one (TL), writing skills are of crucial importance in translating. As pointed out by Leonardi, good writing skills are needed in each stage of the translation process, i.e. in decoding the ST, transferring linguistic and cultural elements and meanings into the TL and encoding the text into the TL by taking into account the target culture (ibid.). Whenever writing skills are taught in FLT, reference is made to focus, organisation, elaboration, style and text conventions, all aspects which are also highlighted in translation and which can therefore efficiently be used to enhance writing skills. Moreover, if a contrastive perspective is adopted (i.e. texts are viewed as culturemes and compared as suggested in 3.2), learners will be able to become acquainted with differences in writing styles in different languages.

Oral skills, i.e. listening and speaking, can be developed and taught through translation that is practised as a communicative activity performed within a meaningful context (cf. Nord 1997). Discussing translational solutions before and after translating a text in a FLT environment by using the FL can trigger a significant degree of interaction between the teacher and the learners and hence provide ample opportunities for the students to improve their oral skills. This type of discussion, along with conducting and performing translation activities, actually provides additional possibilities for classroom communication in the FL and thus for maximizing the learners' exposure to the FL.

By considering translation as an additional language skill which can supplement the traditional four skills, a more comprehensive approach to language learning can be adopted, one where translation is not an end in itself but a tool or a strategy supporting reading, writing, listening and speaking skills. 


\subsection{Insights from TS supporting FLT}

In its initial stages, TS was concerned with the concept of equivalence, i.e. finding target language means which enable the transferring of the source text (or any other relevant language segment) into the target language. This understanding of translation is probably the most diffused one and it can be embraced by language learners at all levels. The concept of equivalence has been tackled by different scholars who essentially viewed it in the light of a binary opposition between two contrasting types, e.g. formal vs. dynamic (Nida 1964), semantic vs. communicative (Newmark 1991), overt vs. covert (House 1981), documentary vs. instrumental (Nord 1991); others, meanwhile, introduced alternative concepts which were still centred on a more or less pronounced degree of "sameness" or approximation to the source or the target language/culture, i.e. domestication vs. foreignisation (Venuti 1995). For FLT purposes, equivalence can be defined simply as the rendering of a message from one language into another while bearing in mind cultural differences and the intended function of the translation (cf. Leonardi 2010: 81).

It was only the functionalist approaches in TS that decidedly shifted the focus from equivalence to the purpose of translation (i.e. the skopos) and actually highlighted the communicative function of translation. From the functionalist perspective, skopos is seen as the factor defining the translation strategy to be applied and the type of translation to be produced, and it is also seen as justifying a wide range of different renderings of the source text (ST), depending on the communicative purpose pursued. In the light of this approach and in accordance with the principles of plurilinguism and pluriculturality as proposed by the CEFR, learners will be made aware of the fact that, in order to effectively communicate across language and cultural barriers, any level of available skills from their intercultural repertory may and should be activated (CEFR 2001: 4-5). The importance of making FL learners aware of the resources provided by their intercultural repertory and its potential in building up plurilinguism and pluriculturality is also endorsed by Ožbot and Currie (2008). Another approach, suggested by the skopos theory and relevant for FLT is that language use should take into account the broader setting in which communication occurs, i.e. the wider context seen as "the constellation of events and situational factors (physical and others), both internal and external to a person, in which acts of communication are embedded" (CEFR 2001: 9). When in a FLT context school leaving certificates are discussed, learners will be made aware of the fact that to be able to compare the sociocultural connotations of school grading systems, the British grading scale using letters, for instance, can be translated with corresponding Slovenian numerical grades, while when discussing the specifics of the British educational system (or in a certified translation of a proficiency certificate) the original grading scheme has to be maintained and, if necessary, an appropriate explanation provided. In this respect the functionalist perspective introduces the concept of cultural embeddedness of language, according to which a message can fully be understood only if embedded in a given situation - a situation which, in turn, is embedded in the context of the culture underlying it.

The idea of the fundamental interrelatedness of language and culture that was introduced by the functionalist approaches paved the way for the so-called "cultural turn" 
in TS, a stance advocated by Bassnett and Lefevere (1990) and best rendered by the following metaphor:

No language can exist unless it is steeped in the context of culture; and no culture can exist which does not have at its centre, the structure of natural language. Language, then, is the heart within the body of culture, and it is the interaction between the two that results in the continuation of life-energy. In the same way that the surgeon, operating on the heart, cannot neglect the body that surrounds it, so the translator treats the text in isolation from the culture at his peril (Bassnett 1991: 14).

In line with this view, FL learners need to grasp that to effectively use a language in intercultural communication the cultures involved (i.e. in FLT the culture underlying L1 and the FL) need to be compared and their similarities and differences taken into account. In addition, to fully acknowledge the interrelatedness of language and culture, communicative situations can be observed in the light of the "cultureme theory", which defines "culturemes" as patterns of communicative behaviour, i.e. as a socio-cultural category, which is realised through realisational and regulatory "behaviouremes". "Realisational behaviouremes" refer to verbal (choice of linguistic means), paraverbal (pitch, tone, prosody) and non-verbal (e.g. gestures, body language) aspects of a communicative act, while "regulatory" ones involve extra-linguistic factors, such as time, space, status, social order, etc. (Oksaar 1988: 26-27). As shown in Kocbek (2013), the cultureme model can also be applied to texts. Texts (in the form of different genres) are regarded as culturally-specific patterns of (written) communicative behaviour consisting of several structural levels. Hence, the cultureme model can be used as a scaffolding strategy in FLT in the process of text reception and/or production. Within this model learners are instructed to first focus on the text macrostructure to identify the culturallyspecific text design and content, and then to examine the microstructural levels to map the lexical, syntactic, pragmatic and stylistic features prototypical of a given genre. In the next stage they are led to adopt a contrastive perspective and compare the identified features of the FL text with the existing text-culturemes in their native culture, or vice versa. Through this process they are made aware of the similarities and differences at the different levels of L1 and FL texts and, when asked to write a text in the FL or produce a translation, they will be encouraged to take into account their findings from the previous analysis of L1 and FL text-culturemes, as well as to conform the text to the intended communicative purpose, i.e. skopos.

Hence, when translating texts in accordance with the skopos theory and following the cultureme model, learners will realise that a source language text can be transferred into a target language in different ways, depending on the communicative purpose, but that the translation will have to conform to the norms and conventions shaping the various dimensions of a spoken or written communicative act. Accordingly, in order to communicate effectively, the language user not only needs to choose the most adequate verbal elements in the FL (i.e. activate his/her linguistic competence), but must also take into account the behaviouremes shaping a particular cultureme in the target culture. This entails drawing on his/her sociolinguistic and pragmatic competences. For instance, in teaching greeting customs, the learners' attention is drawn to the linguistic means available in the FL for 
taking into account both the time of the day and the hierarchical differences between the communicating parties that ensue from their age, standing, gender, etc. - such as polite forms of address by using special pronouns and verb forms (the T-V distinction), or titles to acknowledge the status of the person addressed. In addition, the conventional gestures or body movements accompanying the act of greeting (shaking hands, bowing one's head, lifting one's hat, kissing a lady's hand), the habitual voice pitch, intonation, as well as other paraverbal and nonverbal behaviouremes will need to be considered.

When preparing learners to effectively communicate in writing, the paraverbal dimension will be substituted by paratextual aspects, such as the text layout, illustrations, tables, charts and typographic features (CEFR 2001: 80), while more attention will have to be paid to the text levels in terms of the macro- and microstructure of the text. As far as macrostructure is concerned, each culture has its own text conventions which regulate text design, e.g. the order in which text elements occur, its extent and consequently content (CEFR 2001: 123). On the lexical level, the appropriate vocabulary, e.g. specialized terminology in LSP texts, will have to be used by drawing on the language user's linguistic competence; on the syntactic level, meanwhile, e.g. the prevailing sentence structures, the use of the passive voice, etc. in corresponding FL texts will have to be taken into account. On the pragmatic level, those differences between languages will have to be acknowledged which pertain to the realisation of different speech acts by using language-specific means and involve activating the functional competence according to the CEFR (ibid.: 125-126) - such as expressing obligation with the "shall future" used with third-person subjects in English legal texts versus using lexical verbs such as "obvezati se" or "sich verpflichten" with the same function in Slovene and German, or giving instructions in recipes with an infinitive in Italian versus using the imperative for the same function in English and Slovene. Tackling the stylistic level will involve respecting the level of formality expected in a genre and using conventional linguistic means to achieve it, such as using the passive voice in English and German technical texts. The cultureme model can be applied to texts with differing levels of complexity - from relatively simple and short ones, such as safety warnings, employment advertisements to recipes and business letters, to very complex genres, such as contracts and agreements.

When teaching culturemes both in spoken and in written communication, the regulatory, i.e. extra-verbal aspect requires special attention as it actually affects other text levels by dictating, for instance, the choice of lexical and stylistic means. This dimension is reflected in the language user's sociolinguistic competences (CEFR 2001: 118-119) and covers aspects, such as time and space, i.e. where and when a communicative act takes place (a wedding ceremony in a church or in a registry office requiring the use of specific linguistic formulae), religious norms (e.g. prohibiting the use of certain ingredients in a kosher recipe), the social order (requiring the use of appropriate markers of social relations, such as addressing communication partners with "tovariš/-ica"/"comrade' in the socialist times in ex-Yugoslavia, irrespective of their social status in their native culture), the historical and political embeddedness of a communicative situation, defining e.g. the expected shared knowledge (CEFR 2001: 11) of the communicating parties in situations involving participants with a common historical background, as, for example, regarding 
equivalent legal concepts in Slovene and Austrian law derived from the common legal system of the Austro-Hungarian empire, or recipes such as "Strudel", a traditional pastry known in the whole area formerly belonging to this empire.

By using the cultureme model as scaffolding the whole repertory of communicative competences with their linguistic, sociolinguistic and pragmatic components is developed and acquired by the learner, and this is to be used when acting as a speaker, writer, listener or reader in communicative language processes (CEFR 2001: 90).

When teaching a FL and trying to link it consistently to its underlying culture, teachers may be confronted with the problem of rendering or introducing culturally specific phenomena, ideas, conventions, concepts and cultural practices (such as festivities, traditional folk and fairy tale characters, culinary traditions, deities, folklore elements, etc.) which have no corresponding counterpart in the learners' culture and which, according to Chesterman (1997), can be seen as memes. While memes will usually be transmitted through imitation and language within a culture, their transmission across cultural and linguistic boundaries will only be possible through translation. Thus, translation serves as "a survival machine for memes" (Chesterman 1997: 7), and the very need for translation proves the existence of a cultural boundary. Translation will therefore be indispensable for effectively presenting prototypical features of the FL culture to its learners.

Moreover, translation as advocated by the theory of memes can actually provide an effective tool for highlighting the intercultural dimensions of FLT, as it will enable learners to develop the necessary awareness about culturally-determined speech practices and norms, but also to focus on cross-cultural differences between the two or more cultures involved in communication. Targeted meme-oriented translation activities may involve discussing possible translation equivalents when dealing with culture-specific festivals and celebrations (e.g. the sociolinguistic practices of celebrating Mother's Day or Women's Day, i.e. March 8), mythological and literary characters (e.g. the figure of "Povodni mož" - the Waterman - in Slovenian folk tales and poems), culinary practices (e.g. translating measuring units, spices, special ingredients, etc.), architectural features (e.g. the typical Slovenian hayrack termed "kozolec" or the "trullo", i.e. a traditional Apulian dry stone hut with a conical roof), but also dances (the Greek sirtaki, Spanish flamenco), musical genres (e.g. the Portuguese fado, Bosnian sevdah music), historically and/ or ideologically charged terms such as the German vocabulary used in the Third Reich (e.g. "Rassenschande"/'racial defilement' or "Rassenverrat"/"racial betrayal'), etc. What is more, these activities can be used to initiate more comprehensive discussions regarding mythology, history and its influences as traced in culinary traditions, musical genres, etc. and they can be used to expand the learners' cultural horizon in accordance with the principles of plurilingualism and pluriculturality promoted by the CEFR.

\section{4 "TRANSLATION HAPPENS EVERYWHERE, ALL THE TIME, SO WHY NOT IN THE CLASSROOM."}

As illustrated by McConnell-Duff's words quoted immediately above (1989: 6), while FLT experts have been arguing for and against using translation in FLT, translation has 
been penetrating every pore of contemporary society. With the intensification of migration flows in the last decades more and more people find themselves in situations which require some amount of translation. The very exercising of fundamental human rights, such as the right to medical services, to legal protection, education, etc., can depend on a person's ability to use a FL and/or on the availability of translation. In globalised societies, more and more FL speakers occasionally assume the roles of "natural translators" (Nord 1997: 16) as they volunteer to act as translators and/or interpreters in situations where professional translation or interpreting is not available, or when they intervene at the request of family members or members of the same cultural community who feel more at ease when translation/interpreting is provided by someone they know rather than by professionals. This phenomenon (referred to as "language brokering") has lately been acknowledged and researched by translation scientists and experts from related fields. Several studies presented at the $1^{\text {st }}$ International Conference of Non-Professional Interpreting and Translation held in May 2012 in Forlì, Italy indicate that children and adolescents from immigrant families, who tend to become proficient in a FL more rapidly than their parents, increasingly take on the role of language and culture mediators. To support pluriculturality and plurilingualism these practices should be acknowledged by FLT by integrating the development of the necessary competences in FL curricula.

In addition, when travelling for different purposes or within various mobility programmes, more and more students, professionals, researchers, business people or just ordinary tourists are becoming aware of the need for translation and are looking for targeted education programmes to fill this gap.

\section{CONCLUSION}

In this paper, we have joined the chorus of authors who argue that the dilemma whether or not to include translation in FLT has long found its answer both in the learners' propensity to resort to translation whenever possible, as well as in the increasing demand for translation that is being perceived in all walks of life. Moreover, the current trends in contemporary societies provide sufficient evidence that translation is a legitimate and indispensable component of intercultural communicative competence. In order to develop this competence in a targeted way, the synergies that can be achieved by the mutual informing of TS and FLT should be exploited. To this purpose, research in translation science should also address non-professional translating and interpreting in a systematic manner, while FLT policies (including the CEFR) should endeavour to cater for the real needs of FL learners by developing targeted competences which undoubtedly include some degree of translation. The added value created by this synergetic development is the learners' enhanced intercultural awareness and sensitivity, as well as the instigation of a process of life-long learning, given that (as many professional translators confirm) translation not only enhances and bolsters linguistic proficiency but also declarative knowledge and existential competences. 


\section{References}

BASSNETT, Susan (1991) Translation studies: Revised edition. London/New York: Routledge.

BASSNETT, Susan/André LEFEVERE (eds) (1990) Translation, History and Culture. London/New York: Pinter.

BRATOŽ, Silva/Alenka KOCBEK (2013) "Resurrecting Translation in SLT: A Focus on Young Learners.” In: D. Tsagari/F. Georgios (eds), Translation in Language Teaching and Assessment. Newcastle upon Tyne: Cambridge Scholars Publishing, 135-153.

CARRERES, Angeles (2006) "Strange bedfellows: Translation and Language teaching." In: Sixth Symposium on Translation, Terminology and Interpretation in Cuba and Canada. 15 July 2014. http://cttic.org/ACTI/2006/papers/Carreres.pdf.

CHESTERMAN, Andrew (1997) Memes of Translation. Amsterdam/Philadelphia: John Benjamins.

Common European Framework of Reference for Languages: Learning, Teaching, Assessment (2001). Cambridge: Cambridge University Press. 15 July 2014. http:// www.coe.int/t/dg4/Linguistic/Source/Framework_EN.pdf

COOK, Guy (2010) Translation in Language Teaching. Oxford: Oxford University Press.

GRADDOL, David (2004) “The future of language.” Science 303/5662, 1329-1331.

HOUSE, Juliane (1981) A Model for Translation Quality Assessment. Tübingen: Narr.

HOUSE, Juliane (2012) "Guy Cook: Translation in Language Teaching." Applied Linguistics 33/2, 216-219.

KOCBEK, Alenka (2013) "Translation science as an aid to second language teaching." In: A. Akbarov/D. Larsen-Freeman (eds), Teaching, acquiring and applying intercultural linguistic competence: proceedings book. Sarajevo: International Burch University, 63-72.

KRASHEN, Stephen D. (1982) Principles and Practice in Second Language Learning and Acquisition. Oxford: Pergamon.

LEONARDI, Vanessa (2010) The role of pedagogical translation in second language acquisition: From theory to practice. Bern: Peter Lang.

MALMKJÆR, Kirsten (1998) Translation and Language Teaching: Language Teaching and Translation. Manchester: St. Jerome Publishing.

MCCONNELL-DUFF, Alan (1989) Translation. Oxford: Oxford University Press.

NAIMUSHIN, Boris (2002) "Translation in Foreign Language Teaching: The Fifth Skill." Modern English Teacher 11/4, 46-49.

NEWMARK, Peter (1991) Approaches to Translation. Oxford: Pergamon Press.

NIDA, Eugene A. (1964) Toward a Science of Translating. Leiden: Brill.

NORD, Christiane (1991) Text Analysis in Translation. Amsterdam/Atlanta: Rodopi.

NORD, Christiane (1997) Translating as a Purposeful Activity: Functionalist Approaches Explained. Manchester: St. Jerome.

OKSAAR, Els (1988) Kulturemtheorie: Ein Beitrag zur Sprachverwendungsforschung. Göttingen: Vandenhoeck u. Ruprecht. Hamburg: Joachim Jungius Gesellschaft der Wissenschaften. 
OŽBOT, Martina/Oliver CURRIE (2008) "Evropski jeziki: instrumenti in simboli." Ars \& Humanitas 2/1, 65-81.

PIŽORN, Karmen/Mihaela BRUMEN (2008) "Evropske smernice za učenje tujih jezikov na predšolski in razredni stopnji osnovne šole." Revija za elementarno izobraževanje 1/3-4, 139-146.

PYM, Anthony/Kirsten MALMKJÆR/María del Mar GUTIÉRREZ-COLÓN PLANA (2012) Translation and Language Learning: An analysis of translation as a method of language learning in primary, secondary and higher education. 15 July 2014. http://www.est-translationstudies.org/research/2012_DGT/reports/2012_technical_proposal.pdf

REISS, Katharina/Hans J. VERMEER (1984) Grundlegung einer allgemeinen Translationstheorie. Tübingen: Niemeyer.

TSAGARI, Dina/Georgios FLOROS (eds) (2013) Translation in Language Teaching and Assessment. Newcastle upon Tyne: Cambridge Scholars Publishing.

VENUTI, Lawrence (1995) The Translator Invisibility. New York: Routledge.

WIDDOWSON, Henry G. (2003) Defining Issues in English Language Teaching. Oxford: Oxford University Press.

\section{Summary \\ UNLOCKING THE POTENTIAL OF TRANSLATION FOR FLT}

The paper proposes unlocking the potential of translation for foreign language teaching (FLT) by seeking to create synergies with the related discipline of translation science (TS). This aim is in keeping with the guidelines for language teaching provided in the Common European Framework of Languages, which introduced a model of communicative competences including communicative language competences as those which enable a person to act by drawing on specific linguistic means. First, an overview of the changing status of translation in FLT is presented - from its being considered a fundamental teaching method and basic skill in the Grammar-Translation Method, to its being all but outlawed in more recent communicative and task-based approaches, to its final rehabilitation in recent decades. It is then shown that, in the development of FLT, the parallel evolution of TS somehow failed to be acknowledged and, consequently, the opportunity to create valuable synergies between the two disciplines was missed. Following the stance of authors who have advocated the use of translation in FLT, it is argued that translation can effectively supplement the development of the four traditional language skills and, moreover, that some of the insights developed by TS can effectively be integrated into FLT as strategies aimed at enhancing leaners' cross-cultural communicative competences. To this purpose, selected insights from TS (e.g. the functional approach and the skopos theory, the cultureme model, the theory of memes) are discussed and their potential for creating synergies with FLT are explored. Finally, the 
paper discusses the omnipresence of different forms of translation and interpreting in contemporary societies and shows that this naturally and logically calls for a systematic inclusion of translation in FLT.

Keywords: translation, foreign language teaching, skopos, cultureme, meme.

\author{
Povzetek \\ PREVAJANJE KOT NEIZKORIŠČENI POTENCIAL V \\ POUČEVANJU TUJEGA JEZIKA
}

V članku predlagamo, da se z ustvarjanjem sinergičnih povezav med sorodnima disciplinama tujejezičnega poučevanja in prevodoslovja aktivira potencial, ki ga za tujejezično poučevanje nudi prevajanje. Ta pogled sledi smernicam Skupnega evropskega jezikovnega okvira, s katerim je bil uveden model sporazumevalnih zmožnostih, ki vključuje jezikovne sporazumevalne zmožnosti kot tiste, ki ljudem omogočajo delovanje ob uporabi specifičnih jezikovnih sredstev. S tem v zvezi članek prinaša najprej pregled sprememb statusa prevajanja $\mathrm{v}$ razvoju tujejezičnega poučevanja. Prevajanje je tako v okviru slovnično-prevajalske metode veljalo za temeljno metodo poučevanja in ključno spretnost, bilo nato skoraj tabuizirano v sodobnejših komunikacijskih in na dejavnostih temelječih pristopih ter končno rehabilitirano v zadnjih desetletjih. Prikazali bomo, kako je poučevanje tujega jezika v svojem razvoju nekako spregledalo vzporedni razvoj prevodoslovja in na ta način zamudilo priložnost za vzpostavitev dragocenih sinergičnih povezav med obema disciplinama. Navezali se bomo na stališča avtorjev, ki zagovarjajo uporabo prevajanja pri tujejezičnem poučevanju in poskušali dokazati, da lahko prevajanje učinkovito dopolnjuje razvoj klasičnih štirih jezikovnih spretnosti, kot tudi, da je nekatere pristope, ki jih je razvilo prevodoslovje, mogoče učinkovito prenesti v poučevanje tujega jezika $\mathrm{v}$ obliki strategij namenjenih izboljšanju medkulturnih sporazumevalnih zmožnosti učencev. V ta namen predstavjamo izbrane pristope iz prevodoslovja (npr. funkcionalne pristope s teorijo skoposa, model kulturema, teorijo memov) in raziščemo njihov potencial za sinergično povezovanje s področjem tujejezičnega poučevanja. $\mathrm{V}$ zadnjem delu članek obravnava vsesplošno prisotnost različnih oblik prevajanja in tolmačenja v sodobnih družbah, iz katere se je kot naravna in logična posledica porodila zahteva po sistematični vključitvi prevajanja $\mathrm{v}$ poučevanje tujega jezka.

Ključne besede: prevajanje, tujejezično poučevanje, skopos, kulturem, mem. 